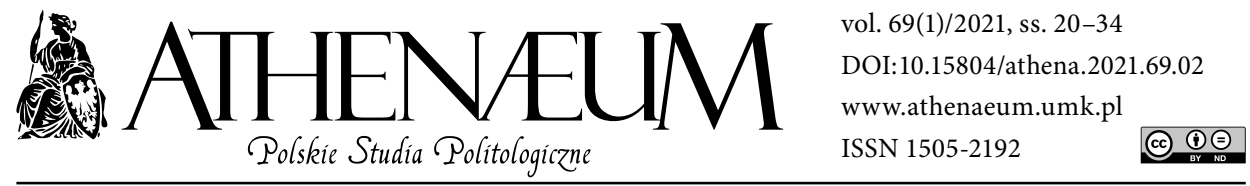

\title{
WOJNA I EKONOMIA W PAŃSTWIE FICHTEGO
}

\author{
WAR AND ECONOMY IN FICHTE'S STATE
}

Bartosz Karol Wójcik*

\begin{abstract}
ABSTRAKT
Celem artykułu jest analiza pojęcia wojny i jej związków z ekonomią w filozofii społecznej J.G. Fichtego, w oparciu o „Zamknięte państwo handlowe”. W pierwszej części naszkicowany zostaje model autarkicznego i racjonalnego państwa, który posiada pewne podobieństwa $\mathrm{z}$ projektem politycznym Grakchusa Babeufa. W tym kontekście poglądy polityczne Fichtego zostają określone mianem „socjalizmu republikańskiego" w kontraście do liberalnej doktryny Immanuela Kanta. W drugiej części zbadane zostają ekonomiczne i geopolityczne przyczyny wojny. Filozof przede wszystkim krytykuje rodzący się globalny rynek kapitalistyczny. Podsumowując, dla Fichtego idea zamkniętego państwa ma gwarantować pokój tak wewnętrzny, jak zewnętrzny. Jednak filozof będący admiratorem rewolucji francuskiej, dopuszcza sytuacje, gdy wojny są etycznie usprawiedliwione.
\end{abstract}

Słowa kluczowe: wojna; ekonomia; rewolucja francuska; Fichte; „Zamknięte państwo handlowe”
The aim of the article is to examine relation of war and economy in Fichte's social philosophy, based on "The Closed Commercial State". The first part describes autarchic and rational concept of state, which has some common ideas with the doctrine of Gracchus Babeuf. Fichte's political views are characterized as "republican socialism" and contrasted with Immanuel Kant's liberal agenda. The second part examines the economical and geopolitical causes of war. Fichte strongly criticizes the awakening of the global capitalist market. To conclude, on the one hand, the idea of closed state guarantees the internal peace in the society and external peace between nations, but on the other hand, Fichte - as the great admirer of the French Revolution - sometimes justifies the necessity of war.

Keywords: economy; war; French Revolution; Fichte; the Closed Commercial State

* Polska Akademia Nauk, Instytut Studiów Politycznych. 


\section{WSTĘP}

Filozofem, który jako pierwszy skonfrontował się z narodzinami nowoczesnego narodu niemieckiego, był Johann Gottlieb Fichte, świadek wojny wyzwoleńczej z lat 1808-1813. Jego czynne zaangażowanie w niemiecką reakcję na kampanie napoleońskie stało się źródłem ambiwalentnych interpretacji jego filozofii politycznej. Dla jednych badaczy Fichte był protoplastą nacjonalizmu i apologetą totalitaryzmu (Kohn, 1949), dla drugich natomiast kontynuatorem kantowskiego racjonalno-liberalnego projektu społecznego (Neuhouser, 1994), dla innych jeszcze radykalnym rewolucjonistą postulującym egalitarystyczno-komunistyczną utopię (Léon, 1914). Doświadczenie wojny stanowiło istotną cezurę w ewolucji intelektualnej myśliciela, który wedle popularnej wykładni: $\mathrm{z}$ oświeceniowego racjonalnego jakobina miał się przeobrazić w religijnego i irracjonalnego proroka niemieckiego mesjanizmu (Heine, 2018, s. 173-174; Balibar, 2007, ss. 111-112). Czy mamy zatem jednego czy przynajmniej dwóch Fichtów? Jakie znaczenia miała sama wojna i namysł nad nią dla uformowania się filozoficznego stanowiska Fichtego? I wreszcie, jak przedstawia się relacja wojny i ekonomii w tejże filozofii? Naszym celem będzie zatem naszkicowanie idei wojny i pokoju w projekcie państwa Fichtego, które wiążą się bezpośrednio z prezentowanym przez niego systemem ekonomicznych i geopolitycznych relacji. Następnie tę ogólną teorię wojny skonfrontujemy ze szczegółowym stanowiskiem Fichtego wobec rzeczywistej wojny rewolucyjnej Francji. Podstawą materiałową dla naszych badań będzie interpretacja tekstów źródłowych filozofa.

Większość komentatorów filozofii politycznej Fichtego koncentruje się na Mowach do narodu niemieckiego (Fichte, 1996d, ss. 273-316), wygłaszanych przez filozofa na przełomie 1807 i 1808 roku w okupowanym przez Francuzów Berlinie. Jednak właściwe rozumienie jego teorii społeczno-politycznej i roli, którą odgrywa w niej wojna, wymaga cofnięcia się do wcześniejszych pism. Mianowicie do dwóch rozpraw, które teoretycznie ugruntowują Fichteański projekt państwa, czyli: Podstaw prawa naturalnego wedle teorii wiedzy z 1796 roku (Fichte, 1996b, ss. 87-149) oraz Zamkniętego państwa handlowego z 1800 roku (Fichte, 1996c, ss. 151-228). W pierwszej pracy zostaje pojęciowo opracowana idea wspólnoty w jej relacji do prawa i moralności, czyli na abstrakcyjnym poziomie Fichte przygotowuje swoje podstawowe kategorie filozofii moralnej i politycznej, których materialną realizacją jest już utopia „zamkniętego państwa handlowego”. Innymi słowy, Podstawy prawa naturalnego dowodzą, że momentem prawa jest 
jego urzeczywistnienie w świecie realnym, Zamknięte państwo handlowe zaś pokazuje, jak urzeczywistnienie to powinno wyglądać.

\section{PAŃSTWO ROZUMU}

Wokół samego Der geschlossene Handelsstaat narosło wiele mitów interpretacyjnych (zob. Balibar, 2007, ss. 121-122), które wielokrotnie znajdowały potwierdzenia w tekście. Fichte we wstępie już zaznacza, że rozwijany przez niego projekt ma charakter postulatu, to znaczy opisuje czysty stan idealny państwa rozumu, takie jak być powinno, a nie państwo rzeczywiste, takie jakie jest w empirycznym świecie: „Państwo rzeczywiste można zatem wyobrazić sobie jako stopniowe wznoszenie się państwa rozumu" (Fichte, 1996c, s. 155). Istnienie zaś państwa rzeczywistego jest koniecznością, nie może być zdaniem filozofa, ludzkiej zbiorowości funkcjonującej wedle prawa poza państwem, powołanego do życia przez pierwotną „umowę obywatelską” (Staatsbürgervertrag). Podobnie jak u Kanta, państwo gwarantuje władzę sankcji egzekucji prawa. W przeciwieństwie jednak do Kantowskiego liberalnego państwa negatywnego - mającego zapewniać ochronę praw i neutralizować skonfliktowane wolności obywateli i całych narodów - przed Fichteańskim państwem stoi ambitne i pozytywne zadanie do zrealizowania. Jego cel jest podwójny: wewnętrzny pokój społeczny i powszechny pokój zewnętrzny. Dwa są także podstawowe instrumenty sprawowania w nim władzy: organizacja i kontrola. Isaac Nakhimovsky tym samym słusznie zauważa, że Zamknięte państwo handlowe można interpretować jako rozwinięcie idei wiecznego pokoju, wpisania jej w szerszy system ekonomiczno-społeczny (Nakhimovsky, 2011, s. 20).

Fichteańskie państwo pomyślane jest jako zapora przed największym zagrożeniem dla pokoju (tak wewnętrznego, jak i zewnętrznego), czyli przed władzą pieniądza - międzynarodowym kapitałem handlowym jako formą imperializmu. Duch handlu, dla Kanta będący praformą powszechnego pokoju, dla Fichtego stanowi „niekończącą się wojnę wszystkich ze wszystkimi” (Fichte, 1996c, s. 202). Dlatego, aby jej zapobiec, rząd ma za zadanie przeprowadzić pełną reglamentację sfery produkcji i wymiany, skutkującą wyłączeniem krajowej gospodarki z globalnego obiegu kapitału. Rola rządu nie ogranicza się zatem do działań prawno-policyjnych, tylko przede wszystkim ekonomicznych. Populacja podzielona zostaje na trzy stany - wytwórców-rolników, przetwórców-rzemieślników/robotników, kupców - których liczebność i zakres działalności jest 
koordynowany przez organy administracyjne. Rząd posiada monopol na handel zagraniczny (zredukowany do minimum) i reguluje zarówno ceny, jak i ilość wytwarzanych towarów. Wprowadzony zostaje „pieniądz krajowy”, niewymienialny na żadną walutę zagraniczną, który ma służyć jedynie do obrotu na rynku wewnętrznym (zob. Fichte, 1996c, s. 183). Słowem, utopia całkowicie scentralizowanej, upaństwowionej, czyli zracjonalizowanej gospodarki planowanej jest odpowiedzią na anarchiczne impulsy leseferystycznej ekonomii potęgującej irracjonalne siły „,wolnej gry rynkowej”: „Zadania państwa pojmowano dotychczas w sposób jednostronny i połowiczny, jedynie upatrując w nim instytucję służącą do utrzymania przy życiu prawa zastanego posiadania obywateli. Przeoczano natomiast głębszy obowiązek państwa, jakim jest zapewnienie najpierw każdemu należnej mu własności. To ostatnie można zaś osiągnąć tyko w ten sposób, iż zlikwiduje się anarchię w handlu tak samo, jak stopniowo znosi się anarchię polityczną, a państwo zamknie się w postaci państwa handlowego, tak samo jak jest zamknięte pod względem swego prawodawstwa i sądownictwa" (Fichte, 1996c, s. 199).

Warto zatrzymać się na moment przy pojęciu własności, ponieważ właśnie ono najlepiej eksponuje linię demarkacyjną oddzielającą Fichtego od tradycji liberalnej, do której bywał często zaliczany (zob. James, 2011, ss. 7-8). Państwo ma „nadać naprzód każdemu jego własność, a potem dopiero - chronić ją” (Fichte, 1996c, s. 157). O jaką własność tutaj chodzi? Nie jest to liberalno-posesywna koncepcja własności jako wyłącznego prawa jednostki do posiadania rzeczy (zob. Turowski, 2014), „tylko wyłączne prawo do działań - nie do rze$c z y$ ” „A zatem to sfera wolnych działań zostaje wskutek umowy podzielona między jednostki i wskutek tego podziału powstaje własność” (Fichte, 1996c, s. 158). Państwo powstałe w wyniku umowy społecznej, ustala przedmiot i zakres działalności jednostki. Tak określony obszar stanowi własność jednostkową, tymczasową i reglamentowaną, ponieważ to rząd, będąc jej ostatecznym gwarantem, może zabronić obywatelowi wykonywania danej czynności (zob. Fichte, 1996c, s. 190). Prawo własności (Eigentumsrecht), ograniczywszy spontaniczną wolność indywidualną (samowolę), staje się warunkiem koniecznym realizacji wolności powszechnej. Pacyfistyczne zadanie państwa - prewencja przed wojną wszystkich ze wszystkim - polega na zapewnieniu każdemu jego własności, tj. na wydzieleniu w gospodarce narodowej miejsca umożliwiającego obywatelowi utrzymanie się z wykonywanej pracy. Prawo do życia z własnej pracy stanowi dla Fichtego podstawowe, naturalne prawo człowieka - uprzednie i w tym sensie transcendentalne wobec pozytywnego i ukonstytuowanego ładu prawnego 
(James, 2011, ss. 33-35) ${ }^{1}$. Dlatego za fundamentalny ekonomiczny cel państwa należy uznać zaprowadzenie takiego porządku społecznego, w którym każdy będzie zdolny do życia ze swojej pracy. Jeśli sam takiej zdolności byłby pozbawiony (jako na przykład osoba niepełnosprawna), to władza publiczna będzie miała obowiązek skompensować ten deficyt w postaci opieki socjalnej. A zatem, scentralizowane i autarkiczne państwo rozumu, będące nieodzownym warunkiem swobodnego i twórczego rozwoju każdego obywatela, jest jednocześnie wzorcem nowoczesnego welfare state, troszczącego się o egzystencję materialną swoich mieszkańców.

Według interpretatora Fichtego, Davida Jamesa, na społeczno-ekonomiczny projekt „zamkniętego państwa handlowego” kluczowy wpływ miała z jednej strony jakobińska konstytucja z 1793 roku (gwarantująca każdemu obywatelowi prawo do szczęścia i zaspokojenia rudymentarnych potrzeb), z drugiej zaś doktryna radykalnego rewolucjonisty i utopijnego komunisty Françoisa (Grakchusa) Babeufa (zob. James, 2011, ss. 56-86). Analogie pomiędzy Fichteańskim państwem rozumu a poglądami autora Manifestu równych znajdziemy w zakresie dwóch zagadnień.

Po pierwsze Fichte i Babeuf za warunek egalitarnego państwa uznają powszechny obowiązek pracy („Kto nie chce pracować, niech też nie je!”; 2 Tes 3,10 ), co w oczywisty sposób uderza w hierarchiczny porządek feudalny, gdzie klasy panujące żyją z wyzysku pracy innych. Tymczasem rząd powinien zapewnić pracę każdemu obywatelowi, podobnie jak bezpośrednio z nią powiązane równe prawo do odpoczynku. Wolność do pracy swój konieczne uzupełnienie znajduje w wolności od pracy: „Człowiek powinien pracować, ale nie jak zwierzę juczne, które uginając się pod ciężarem zapada w sen i po chwili najbardziej niezbędnego pokrzepienia wyczerpanych sił jest ponownie zmuszane do niesienia dalej tego samego ciężaru. Powinien pracować wolny od strachu, z przyjemnością i radością, i mieć jeszcze dość czasu, by wznieść swojego ducha i swój wzrok ku niebu, do oglądania którego jest stworzony. (...) Na tym właśnie powinien polegać dobrobyt narodu - nie paru jednostek, których najwyższy dobrobyt jest widomym znakiem i prawdziwą przyczyną niedomagania narodu. Powinien on więc rozkładać się w równej mierze mniej więcej na wszystkich" (Fichte ,1996c, s. 175).

1 Jak zauważa Marek Siemek, zasadnicza różnica między Kantem a Fichtem w kontekście relacji polityki i moralności, sprowadza się do tego, że dla pierwszego moralność jest warunkiem prawa, dla drugiego zaś prawo warunkiem moralności. Moralnym podmiotem możemy się stać dopiero za pośrednictwem instytucji państwa rozumu (zob. Siemek 2017, ss. 65-66). 
O czasie wolnym, pozwalającym na spontaniczną, ludzką kreatywność, powiada Fichte: „Jest to jego prawo, wynikające wyłącznie z tego, że jest człowiekiem” (Fichte, 1996c, s. 175). Zauważmy jednak, że egalitaryzm „zamkniętego państwa handlowego" niejako uprzywilejowuje uczonych i artystów. Myśliciel czy wynalazca, z powodu charakteru wykonywanej aktywności, „nie zaspokoiłby nawet w stopniu elementarnym swoich potrzeb, gdyby się miał odżywiać tak jak rolnik" (Fichte, 1996c, s. 171). Podobnie, tylko uczeni i artyści posiadaliby prawo do podróżowania, ponieważ na ich wymianie kulturowej $\mathrm{z}$ innymi narodami mogłoby zyskać całe państwo, wzbogacając własny rozwój duchowy (zob. Fichte, 1996c, s. 240). Jak widzimy, owo uprzywilejowanie dotyczy przede wszystkim kapitału symboliczno-kulturowego, ale nie ekonomicznego. Ten ostatni podlega równej dystrybucji: „W tym państwie wszyscy są sługami całości i otrzymują za to sprawiedliwy udział w tej całości. Nikt nie może się szczególnie wzbogacić, ale też nikt nie może zbiednieć" (Fichte, 1996c, s. 172). Babeuf wyciąga z tego programu równości radykalną konsekwencję, która nie pojawia się u Fichtego. Skoro nie powinno być ani biednych, ani bogatych, to jeśli w realnym świecie są bogaci, to należy ich - jako wrogów ludu - wywłaszczyć (zob. James, 2011, s. 76). Niemiecki filozof nie zastanawia się natomiast nad przejściem od aktualnego stanu społeczeństwa do czystego państwa rozumu. Formułując mało konkretny postulat stopniowych reform, $\mathrm{w}$ istocie rejteruje przed samym problemem.

Stanowisko Fichtego najbliższe jest „komunizmowi agrarnemu” Babeufa w odniesieniu do własności ziemi (zob. Dardot, Laval, 2019, ss. 241-242). W „zamkniętym państwie handlowym” nie ma prywatnej własności ziemi ani środków produkcji. Własność prywatna ogranicza się tylko do posiadania pieniądza krajowego oraz artykułów konsumpcyjnych (zob. James 2011, s. 77). „Zgodnie z naszą teorią - argumentuje Fichte - w ogóle nie ma czegoś takiego, jak własność ziemi, przynajmniej dopóty, dopóki ci którzy przyjmują jej istnienie (...) dopóki, powiadam, nie wytłumaczą nam, w jaki sposób takie prawo własności ma być wyegzekwowane w rzeczywistym życiu” (Fichte, 1996c, s. 191).

Można się zastanawiać, na ile paralelność ekonomicznych postulatów Fichtego i Babeufa nie wynikają ze wspólnego im oświeceniowego pragnienia świata totalnie uregulowanego wedle racjonalnych prawideł. Wydaje się, że szczególnie u Fichtego o centralistyczno-kolektywnym charakterze państwa przesądzała jego hiperrozumna struktura: regulacji, nadzoru i kontroli. Nic nie mogłoby wymknąć się tej doskonale zestrojonej administracyjno-ekonomicznej machinie, która reprodukowałby się, bez żadnego kontaktu z zewnętrzem. Autarkiczne zamknięte państwo handlowe to zmaterializowany idealistyczny Absolut. Nic dziwnego, 
że wizja ta zrodziła się w momencie rozpadu archaicznej i feudalnej Rzeszy Niemieckiej, której nieprzejrzysty i zagmatwany ustrój polityczno-społeczny (ze wszystkimi swoimi hierarchiami, przywilejami i zwyczajami) stał w sprzeczności z pojęciem rozumności.

W Kantowskim projekcie liberalnego republikanizmu ostatecznym gwarantem powszechnego pokoju miał być wolny handel, a panowanie globalnego pieniądza nazwane zostało kosmopolityczną federacją państw - światową mieszczańsko-kapitalistyczną sferą publiczną (zob. Kant, 2005, ss. 164-203). W utopii Fichtego przeciwnie, to właśnie międzynarodowy kapitał stanowi największe zagrożenie dla pokoju wewnętrznego i zewnętrznego. Ochroną przez jego globalizmem, odpowiedzialnym za wojny toczące się w Europie, globalizmem przyjmującym formę napoleońsko-polityczną bądź brytyjsko-ekonomiczną, staje się wyłącznie „zamknięcie handlowe państwa w jego naturalnych granicach”, tj. wyłączenie go z rynku światowego. Dlatego, względem liberalnej propozycji Kanta ów projekt można określić mianem socjalizmu republikańskiego, będącego alternatywnym modelem nowoczesnego uspołecznienia dla Niemiec ${ }^{2}$. Socjalistyczny jest u Fichtego jego egalitarny kolektywizm, program ekonomiczny, republikański zaś jego centralistyczny etatyzm, program polityczny. Cel zatem jest podobny jak u Kanta, zapośredniczenie polityki i społeczeństwa, greckiego obywatela i nowoczesnego mieszczanina - wzniosłości ogólności i bezpieczeństwa prywatności.

\section{EKONOMIA POLITYCZNA WOJNY}

Choć doświadczenie wojen niewątpliwie było dla Fichtego bodźcem do opracowania koncepcji „zamkniętego państwa handlowego”, to samej wojnie jako fenomenowi polityczno-prawno-społecznemu filozof nie poświęcił wcale wiele miejsca w swoich pismach. Wojna, podobnie zresztą jak Kanta, interesowała go głównie w perspektywie prawa i ekonomii. To w tym drugim obszarze Fichte zaproponował oryginalną i nowatorską na swoje czasy teorię. W sensie prawnym (przedstawionym w Podstawach prawa naturalnego) wojna to po prostu konsekwencja zerwania umowy pomiędzy dwiema skonfliktowanymi wolami

2 Nakhimovsky, choć nie pisze to socjalizmie republikańskim, to wskazuje na Fichtego jako źródła inspiracji dla idei narodowej samowystarczalności Johna Maynarda Keynesa i Gunnara Myrdala, którzy w dwudziestym wieku odnowili ideę „zamkniętego państwa handlowego” (Nakhimovsky 2011, s. 176-179). Socjaldemokratyczne welfare state może zatem szukać swoich teoretycznych źródeł u niemieckiego filozofa. 
prywatnymi: jeśli żadna ze stron nie chce ustąpić częściowo ze swoich roszczeń na rzecz drugiej i tym samym wypracować kompromisu, dochodzi wówczas do wojny, która nie jest „żadnym stanem prawnym” (Fichte 1996b, 135). Fichte uznaje wojnę za zawieszenie stanu prawnego, który opiera się na wzajemnej umowie, umocowanej na intersubiektywnym porozumieniu pomiędzy uczestnikami zbiorowości. Filozof nie zastanawia się nad sytuacją, gdy walczą ze sobą dwie strony, które nie uznają się wzajemnie za odrębne państwa i właśnie wojna toczy się o uznanie jednej przez drugą (na przykład w sytuacji kolonii, która wyzwala się z metropolii). Wojna przed umową, czyli uprzednia wobec stanu prawnego, całkowicie umyka w prawnej analizie Fichtego. Zapoznanie wskazuje na niewątpliwe ograniczenie tej perspektywy, która ujmuje raczej stan normatywny (to jak powinny wyglądać konflikty międzypaństwowe) niż empiryczny (to jak rzeczywiście wyglądają).

Natomiast w swoich rozważaniach gospodarczych Fichte wychodzi od rozpoznania globalnego rynku jako układu domyślnego, który determinuje kształt relacji międzynarodowych (konstelację tę określa on mianem „wielkiego państwa handlowego"). Europa, wraz ze swoimi koloniami i rynkami zależnymi, tworzy wciąż jeden organizm gospodarczy, co stanowi spuściznę jedności średniowiecznego świata chrześcijańskiego. Jednakże w nowożytności wyłoniły się na Starym Kontynencie liczne wzajemnie zantagonizowane struktury państwowe, których partykularny byt ekonomiczny stoi w sprzeczności z ogólnym europejskim wspólnym rynkiem. Dlatego owo „wielkie państwo handlowe” i jego instytucje, z pieniądzem światowym na czele ${ }^{3}$, stanowią „residua i skutki ustroju, który dawno już został zniesiony, są odpryskami pewnego dawnego świata, nie pasującymi już do naszej rzeczywistości” (Fichte, 1996c, s. 199). O ile Kant przyszłość widział w postępującej gospodarczej integracji Europy i konsolidacji wspólnego rynku na skalę światową, o tyle dla Fichtego wizja ta zapoznaje istotowe różnice ekonomiczne pomiędzy poszczególnymi krajami. Jak to rozumieć? Dlaczego globalny wolny handel jest zjawiskiem tak szkodliwym i niebezpiecznym?

Państwa wchodzące w skład światowego organizmu handlowego są wewnętrznie zróżnicowane pod względem gospodarczym. Jedne są zasobne

3 Fichte definiuje go w sposób następujący: „Jako wspólny środek wymiany obowiązywał wszędzie złoty i srebrny pieniądz, który we wszystkich częściach tego wielkiego państwa handlowego miał niemal te samą wartość i bez przeszkód funkcjonował między nimi” (Fichte, 1996c, 198). Pieniądz światowy to dla niego przede wszystkim ogólny środek cyrkulacji towarów w zglobalizowanym państwie handlowym. Jako alternatywę dla niego filozof proponował - wspomniany już - pieniądz krajowy, który były przeznaczony tylko dla rynku wewnętrznego. 
w gotówkę, surowce mineralne czy infrastrukturę wytwórczą, drugie zaś są np. biedne i przeludnione. Stwarza to oczywistą nierównowagę strukturalną, na której korzystają silniejsze narody kosztem słabszych. Wraz z rozwojem światowej populacji, ekspansją nowych rynków i wzrostem towarów w obiegu, napięcia oraz konflikty w „wielkim państwie handlowym” intensyfikują się: „W ten sposób wśród handlującej publiczności dochodzi do niekończącej się wojny wszystkich przeciw wszystkim, w której nabywcy walczą ze sprzedawcami; wojna ta przybiera na gwałtowności i niesprawiedliwości, a jej skutki stają się coraz bardziej niebezpieczne w miarę tego, jak wrasta zaludnienie świata, powiększa się państwo handlowe w wyniku nowych zdobyczy, rozwija się produkcja i umiejętności, a w rezultacie wchodzi w obieg coraz więcej towarów, co z kolei zwiększa i różnicuje potrzeby wszystkich. To co przy prostym sposobie życia narodów odbywało się bez wielkich niesprawiedliwości i ucisku, w skutek wzrostu potrzeb obraca się w najbardziej krzywdzące bezprawie i źródło strasznej nędzy" (Fichte, 1996c, s. 202).

Globalizacja gospodarcza przy jednoczesnym zwiększaniu liczby światowych konsumentów i ich potrzeb prowadzi do nieuchronnej anarchii, stanowiącej preludium do wybuchu wojny. Fichte rozpoznaje tutaj kluczową sprzeczność nowoczesnego kapitalizmu (analizowaną potem przez Hegla i Marksa), że wzrost dobrobytu - rozwój sił wytwórczych i towarów na rynku - pociąga za sobą wzrost nędzy. Ponieważ uczestnicy światowej wymiany dzielą się na bogatych i biednych, beneficjentów i wyzyskiwanych - owoce globalnej prosperity nie są dystrybuowane po równo (zarówno w obrębie samych państw, jak i pomiędzy nimi).

W tym układzie, jakim jest „światowa republika handlowa” (forpoczta Kantowskiej kosmopolitycznej federacji), jedne narody zawsze będą zyskiwały kosztem innych - utrwalając jedynie podział na silnych i słabych. Symptomem tej szkodliwej nierównowagi jest „powszechna, ukryta wojna handlowa” (Fichte, 1996c, s. 210): „Konflikt interesów handlowych - zauważa Fichte - jest często prawdziwą przyczyną wojen wszczynanych pod jakimś innym pretekstem. Zdarza się, iż połowa świata zostaje zjednana do walki przeciw, jak to się mówi, politycznym zasadom jakiegoś ludu, podczas gdy tak naprawdę wojna wymierzona jest w jego handel, i to ostatecznie ze szkodą dla zjednywanych" (Fichte, 1996c, s. 210).

A zatem jawna ideologiczno-polityczna przyczyna wojny skrywa tylko jej rzeczywistą, ukrytą przyczynę materialną - interes ekonomiczny. Kontekstem dla tej Fichteańskiej hermeneutyki podejrzeń są wojny koalicji z rewolucyjną Francją 
(„połowa świata zjednana przeciwko zasadom politycznym jednego ludu”). Tak należałoby wytłumaczyć zaangażowanie w konflikt Wielkiej Brytanii - głównej siły sprzymierzonej we wszystkich odsłonach koalicji - która dążyła do wyeliminowania swojego największego rywala w walce o globalną dominację handlową, zarówno na morzach (kolonie), jak i na kontynencie (rynek europejski) (Zob. Hobsbawm, 2013, s. 127). Zresztą na pokonaniu Francji właśnie ona zyskała najbardziej, umacniając swoją pozycję globalnego mocarstwa handlowego, o czym filozof jeszcze nie mógł wiedzieć w 1800 roku, ale co już słusznie przewidział (wojna z Francją pod dyktando Anglii okazała się „ostatecznie ze szkodą dla zjednywanych" - tj. państw koalicji - całkowicie uzależniając ich gospodarczo od brytyjskiego kapitału $)^{4}$. Dla Fichtego remedium na ów imperializm gospodarczy miało być wspomniane „handlowe zamknięcie państwa” gwarantujące narodową samowystarczalność - warunek konieczny „utrzymania spokoju wewnętrznego i zewnętrznego".

Analiza przebiegu zamknięcia państwa handlowego zawiera nowatorską na gruncie klasycznej filozofii niemieckiej refleksję geopolityczną, tj. na temat relacji między wojną a geografią. Fichte wprowadza pojęcie „naturalnych granic” państwa, czyli takiego obszaru geograficznego zamieszkałego przez dany lud, który umożliwia mu „produkcyjną samoistność i samowystarczalność” (Fichte, 1996c, s. 220). Państwa nowożytnej Europy są podzielone wedle arbitralnych kryteriów politycznych i dlatego narody nie żyją w swoich naturalnych granicach, co stanowi, główny powód podboju i terytorialnej ekspansji. Pisze Fichte: „Przywilejem filozofa było zawsze wzdychać nad wojnami. Autor nie kocha ich bardziej niż inni, ale, jak sądzi, w obecnym stanie rzeczy są one nieuniknione i uznaje za niecelowe uskarżanie się na to, co nieuniknione. Jeśli chce się zlikwidować wojny, to musi zostać zlikwidowany ich powód. Każde państwo musi uzyskać to, co chciałoby uzyskać poprzez wojnę, a zgodnie z rozumem może ono chcieć tylko uzyskania swoich naturalnych granic" (Fichte, 1996c, s. 221).

Wniosek, który płynie $\mathrm{z}$ tego, dla jego projektu pokoju jest następujący: „Państwo, które zamierza zamknąć się jako państwo handlowe, musi wprzódy, w zależności od sytuacji, albo poszerzyć, albo zawęzić swoje granice, by znaleźć się w granicach naturalnych" (Fichte, 1996c, s. 221).

Jak widzimy, efektywne zamknięcie państwa dokonuje się tylko w ramach terytorium określonego geograficznie i kulturowo. Filozof nie podaje jednak kry-

4 O wpływie ekonomicznie rywalizacji brytyjsko-francuskiej na projekt Fichtego, zob. Nakhimovsky, 2011, ss. 79-104. 
teriów wyróżniania i wydzielania tych naturalnych granic pomiędzy państwami. Czy to same narody posiadałby naturalna intuicję istnienia swoich naturalnych granic (jak wówczas wyjaśnić wtedy nieustające konflikty terytorialne)? Czy może byłaby jakaś rozumowa instancja granice takowe wyznaczająca (jaki byłby jej status wobec „Zamkniętych państw handlowych”, czy nie byłaby ciałem quasi-federalnym)? Czy wreszcie byłyby one rezultatem historycznych walk między państwami (ale wtedy nie byłyby żadnymi „naturalnymi” granicami tylko „politycznymi” par excellence)? Innymi słowy, wątpliwości te można wyrazić w formie paradoksu: warunkiem możliwości „zamkniętego państwa handlowego” samodzielnie wycofującego się z globalnego układu handlowo-politycznego jest nowy globalny układ domyślny, dokonujący podziału istniejących państw wedle ich granic naturalnych. Ktoś z zewnętrz musi wyznaczyć granicę naturalną, aby państwo mogło się od wewnątrz w niej zamknąć. Samo to państwo mogłoby się w pełni zamknąć handlowo dopiero w momencie, gdy inne państwa ościenne również, takiego zamknięcia by dokonały - tworząc światowy ład naturalnych granic, związek zamkniętych państw. Sam Fichte pozostaje tutaj niekonsekwentny, rozdarty pomiędzy trzeźwa Realpolitik ekonomiczno-geograficznych przyczyn wojny a utopijnym marzeniem o nowej równowadze światowej, ustanowionej przez autarkiczne organizmy państwowe, w magiczny sposób zamknięte w swych naturalnych granicach.

Zanim jednak autor Teorii wiedzy zajął się opracowywaniem swojej utopii, trafnie już rozpoznał problem ekonomicznych zależności w światowym porządku handlowym jako potencjalnego źródła wojennych konfliktów. Świadczy o tym wczesna publikacja z 1793 roku Przyczynek do sprostowania sądów publiczności o Rewolucji Francuskiej (zob. Fichte 1996a, ss. 47-101), napisana zresztą jeszcze w trakcie trwania wojny Francji z Prusami. Fichte zainspirowany aktualnymi wydarzeniami polemizuje z ideą „równowagi europejskiej”, oficjalnie wprowadzoną wraz z traktatem westfalskim i uzasadnianą klasyczną teorią polityczną, wedle której podmiotem dziejów nie są jednostki i ludy, tylko monarchowie i rządy (zob. Balibar, 2007, s. 121). Właśnie w tym tekście obnażona zostaje fałszywa jedność Europy jako wspólnego systemu polityczno-gospodarczego, którego jedynym spoiwem jest w rzeczywistości lęk przed wojną. Jak czytamy w rozprawie: „Mówicie, że skoro tylko obali się ją [równowagę sił w Europie], wywiąże się straszliwa wojna jednego przeciw wszystkim, a ten jeden pochłonie wszystkich. A więc, tak bardzo boicie się ze względu na nas tej jednej wojny, która - jeśli wszystkie narody byłby zjednoczone pod jednym przywództwem - zrodziłaby z siebie wieczny pokój? Tej jednej [wojny] boicie się, i po to by nas 
przed nią uchronić, wplątujecie nas w [wojnę] nieustanną? Obawiacie się, że zostaniemy ujarzmienie przez obcą potęgę, i po to, by zabezpieczyć nas przed tym nieszczęściem, wolicie ujarzmić nas sami? [...] Całkowite zniesienie równowagi [sił] w Europie nigdy nie mogłoby być tak szkodliwe dla narodów, jak nieszczęsne było jej utwierdzenie" (Fichte, 1996a, s. 91).

Fichte występuje tutaj jako entuzjasta francuskiej wojny rewolucyjnej, postrzegając ją jako jutrzenkę nowej epoki pokoju wolnej od despotyzmu. Wobec tego za konieczny warunek przyszłego pokoju uznaje wojnę, która położy kres europejskiej równowadze sił, czyli panowaniu feudalno-monarchicznego ładu. Z rozważań tych wyłania się ciekawa dialektyka: jedna totalna wojna - totalna zarówno w sensie swojego powszechnego charakteru, jak i radykalnego wymiaru (skoro ma znieść istniejący system) - przeciwko mniejszym „nieustannym wojnom” (rozumianym tradycyjnie), położy ostateczny kres wojnie jako takiej, zaprowadzi bowiem wieczny pokój.

\section{ZAKOŃCZENIE: JAKOBIN NA WOJNIE}

Choć Przyczynek... i Zamknięte państwo handlowe różnią się co do środka prowadzącego do zapanowania pokoju (wojna totalna rewolucyjnego narodu versus zamknięcie się narodu w naturalnych granicach), przyczyny wojny pozostają analogiczne: równowaga europejska, której ekonomiczną postacią jest wspólny rynek. Wolna wymiana handlowa i „pieniądz światowy” - wedle Fichtego - ściśle korespondują z postwestfalskim porządkiem prawno-politycznym i jako takie stanowią anachroniczną, nieprzystającą formę dla rodzącego się nowoczesnego narodu obywatelskiego.

W młodzieńczym tekście filozofa pobrzmiewa jeszcze jedna rzecz warta uwagi: tymotejski ton wzniosłej wojny. Nic dziwnego, że podziw dla heroizmu republikańskiej armii ustanawiającej nad Renem nowe stosunki społeczne sprowokował Fichtego do greckiego z ducha sądu gloryfikującego wojnę: „Mawiają, że wojna kształci; i to prawda, otwiera ona nasze dusze na doznania heroiczne i usposabia je do takichże czynów, do pogardy dla niebezpieczeństw i śmierci, do lekceważenia dóbr, które codzienne wystawiane są na grabież, do najgłębszego współczucia wszystkiemu, co nosi ludzkie oblicze, gdyż wspólne niebezpieczeństwo lub cierpienie silniej łączy ich z nami; ale nie uważajcie tego czasem za mowę pochwalną na cześć waszej krwiożerczej żądzy krwi, za skierowaną do was pokorną prośbę ludzkości, abyście wszak nie zaprzestali przypadkiem rujnować 
jej w krwawych wojnach jednych z drugimi. Tylko takie dusze wojna wznosi do heroizmu, które mają już w sobie moc; nieszlachetnych inspiruje do grabieży i do gnębienia bezbronnych słabeuszy; wojna wydała bohaterów i tchórzliwych złodziei, a których zaiste w większej ilości?” (Fichte, 1996a, s. 87).

Argument usprawiedliwiający tu wojnę bardzo przypomina ten, którym posłużył się Kant w Krytyce władzy sądzenia (zob. Kant, 2004, ss. 160-161): wojna hartuje ducha, wzbudzając pogardę wobec śmierci i niebezpieczeństwa, a przede wszystkim uwalnia od mieszczańskiego ducha banauzyjskiego, który nieustannie zajmuje się ekonomicznymi interesami i kalkulacjami. Jednak autor wprowadza tutaj rozróżnienie, którego na próżno by szukać w Kantowskiej filozofii - moralną dyspozycję podmiotu prowadzącego wojnę. To, czy mamy do czynienia z „krwiożerczą i grabieżczą” inwazją czy z bohaterską walką, zależy od tak od moralności aktora wydarzeń, jak od moralnego charakteru samego celu prowadzonej wojny. To znaczy od tego, czy zmierza do postępu wolności, panowania rozumu nad dziejami, czy do zniewolenia, regresu do naturalnego barbarzyństwa. Szlachetna i uwznioślająca wojna, którą prowadzi francuski obywatel przeciwko ancien regime, nie jest tą sama wojną, jaką kontrrewolucyjne siły sprzymierzone prowadzą z rewolucją. Mimo że na poziomie empirycznym są tym samym brutalnym i straszliwym wydarzeniem, to w perspektywie etycznej walka ta dzieli się na dobra rewolucyjną i złą reakcyjną. Jedna sprzyja rozwojowi ludzkiej wolności w dziejach, druga zaś postęp ten hamuje. Fichte więc już od samego początku ujmuje wojnę nie w horyzoncie abstrakcyjnego oświeconego moralizmu, dla którego wojna sama $w$ sobie jest złem absolutnym a pokój jedynym dobrem, lecz w konkretnej perspektywie historycznej, dla której w tym okrutnym spektaklu jest dobra i zła storna konfliktu. Do głosu bowiem dochodzi Fichte-jakobin (zob. Beiser, 2016, ss. 38-64).

Podsumowując: Fichteański projekt polityczny socjalizmu republikańskiego swoim radykalizmem (całkowita likwidacja feudalizmu, nacjonalizacja ziemi i gospodarki oraz demokratyczny egalitaryzm) wyprzedzał niemal wszystkich mu współczesnych i antycypował agendę niemieckich lewicowych demokratów z rewolucji 1848 roku (zob. Streisand, 1981, s. 81). Natomiast wobec samej wojny Fichte jako publiczny intelektualista pozostawał niezdecydowany, choć filozoficznie był wobec niej konsekwentny. Czasami ulegał fascynacji wojną, którą estetyzował czy nawet fetyszyzował w swoich pismach (jak wówczas, gdy spoglądał na rewolucyjną levée en masse maszerującą zza Renu). Można to tłumaczyć retoryczną potrzebą reagowania na burzliwe okoliczności, w których się znajdował. Innym razem widział w niej największe zagrożenie i skandal moralny, 
dla którego nie powinno być miejsca w rozumnej rzeczywistości. Jednak w sensie spekulatywnym Fichte ujmował wojnę dialektycznie: rozpoznawał w niej konieczny, acz okrutny moment rzeczywistości, który może stać się wehikułem przyszłego postępu wolności, a tym samym - jedynego gwaranta prawdziwego pokoju. Jednak, czy taki postęp się realizował czy nie, zależało już od moralności aktorów wojennych, których filozof nieustannie pragnął wychowywać do wolności.

\section{BiBLIOGRAFIA:}

Balibar, E. (2007). Trwoga mas. Polityka i filozofia przed Marksem i po Marksie. Tłum. A. Staroń. Warszawa: Wydawnictwo Akademickie „Dialog”.

Beiser, F. (2016). Fichte and the French Revolution. W: D. James, G. Zöller (red.). The Cambridge Companion to Fichte. Cambridge: Cambridge University Press.

Dardot, P., Laval, Ch. (2019). Common: On Revolution in the $21^{\text {st }}$ century, London \& New York: Bloomsbury Academic.

Fichte, J.G. (1996a). Przyczynek do sprostowania sądów publiczności o Rewolucji Francuskiej (fragment). Tłum. R. Marszałek. W: J.G. Fichte, Zamknięte państwo handlowe i inne pisma polityczne. Tłum. P. Dybel, R. Marszałek, J. Nowotniak, R, Reszke. Wstęp: A. Ochocki (ss. 47-101). Warszawa: Fundacja Aletheia.

Fichte, J.G. (1996b). Podstawy prawa naturalnego wedle teorii wiedzy. Tłum. P. Dybel. W: J.G. Fichte, Zamknięte państwo handlowe i inne pisma polityczne (ss. 87-149).

Fichte, J.G. (1996c). Zamknięte państwo handlowe. Tłum. J. Nowotniak. W: J.G. Fichte, Zamknięte państwo handlowe i inne pisma polityczne (ss. 151-228).

Fichte, J.G. (1996d). Mowy do narodu niemieckiego. Tłum. P. Dybel, R. Reszke. W: J.G. Fichte, Zamknięte państwo handlowe i inne pisma polityczne (ss. 273-316).

Heine, H. (2018). Z dziejów religii i filozofii w Niemczech. W: H. Heine, O Niemczech i o sobie. Wybór pism. Tłum. T. Zatorski (ss. 35-190). Warszawa: Fundacja Augusta hr. Cieszkowskiego.

Hobsbawm, E. (2013). Wiek rewolucji. 1789-1848. Tłum. M. Starnawski, K. Gawlicz, Warszawa: Wydawnictwo Krytyki Politycznej.

James, D. (2011). Fichte's Social and Political Philosophy. Property and Virtue, Cambridge: Cambridge University Press.

Kant, I. (2005). Do wiecznego pokoju. Tłum. M. Żelazny. W: I. Kant, Rozprawy z filozofii historii. Wstęp: T. Kupś (ss. 164-203). Kęty: Wydawnictwo Antyk.

Kant, I. (2004). Krytyka władzy sądzenia. Tłum. J. Gałecki, Warszawa: Wydawnictwo Naukowe PWN.

Kohn, H. (1949) The Paradox of Fichte's Nationalism, Journal of the History of Ideas, 10(3), 319-343.

Léon, X. (1914). Le socialism de Fichte d'aprés létat commercial fermé, Revue de métaphysique et de morale, 22, 197-220. 
Nakhimovsky, I. (2011). The Closed Commercial State: Perpetual Peace and Commercial Society from Rousseau to Fichte, Princeton \& Oxford: Princeton University Press.

Neuhouser, F. (1994). Fichte and the Relation between Right and Morality. W: D. Breazeale, T. Rockmore (red.). Fichte: Historical Context/Contemporary Controversy. Atlantic Highlands: Humanities Press.

Siemek, M.J. (2017). Spontaniczność i refleksja. O problematyce wolności $w$ filozofii Fichtego. W: M.J. Siemek, Fichte w kontekście (ss. 35-86). Warszawa: Wydawnictwo Uniwersytetu Warszawskiego.

Streisand, J. (1981). Johann Gottlieb Fichte a historia niemiecka. W: B. Mikołejko (red.). $Z$ historii rozwoju klasycznej burżuazyjnej filozofii niemieckiej. Kant, Fichte, Schelling, Hegel, Feuerbach (ss. 77-109). Tłum. K. Krzemień-Ojak. Warszawa: Książka i Wiedza.

Turowski, M. (2014). C.B. Macpherson: „indywidualizm posiadaczy” a dylematy wspótczesnej ontologii politycznej, Wrocław: Wydawnictwo Uniwersytetu Wrocławskiego. 